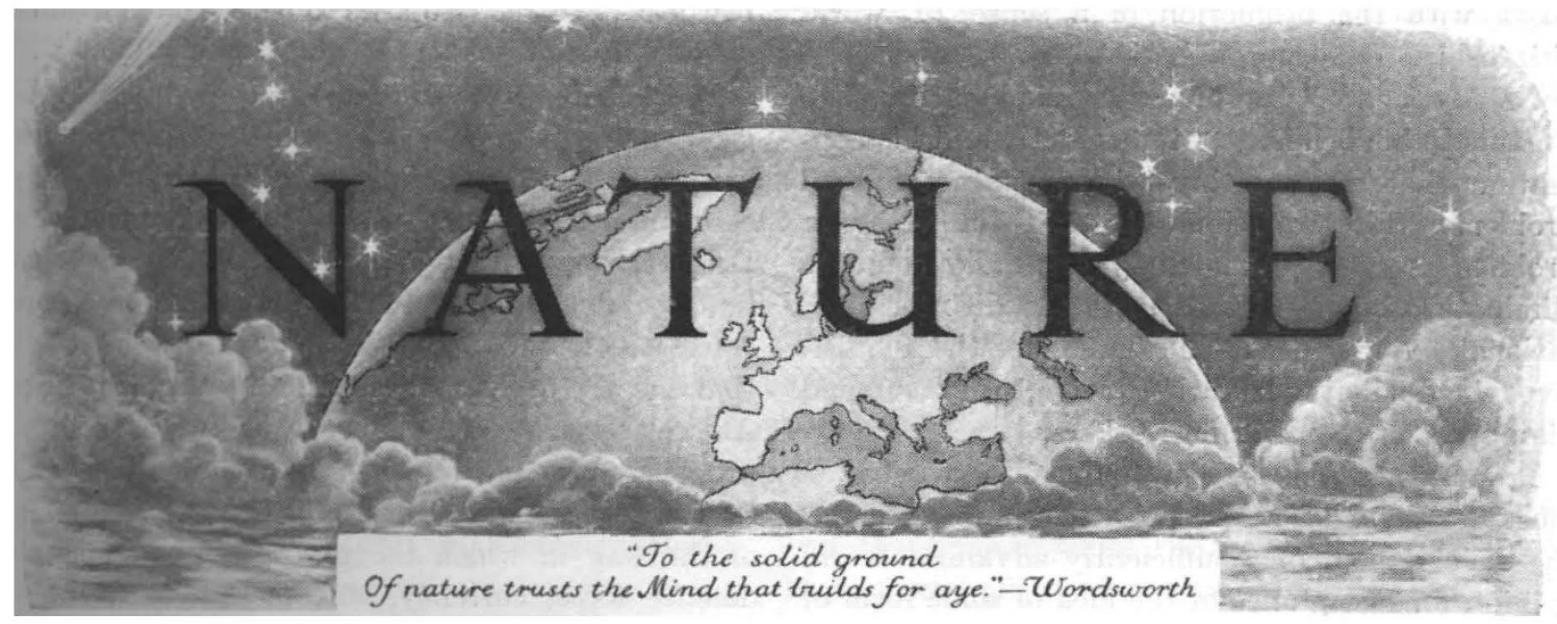

Vol. 145

SATURDAY, JANUARY 6,1940

No. 3662

\title{
RECONSTRUCTION IN EUROPE
}

$\mathbf{E}$ VEN in the stress and strain of the war itself, the widespread concern as to the steps to be taken to ensure that our efforts are not once again in vain is unmistakable. Only the creation of a new order founded on truth and justice can compensate for the sacrifices that have to be made, and the creation of such an order involves the co-operation both of belligerents and of neutrals. The extent to which this is evident is one of the most significant differences in the present temper of the nation in contrast with its entry into war in 1914.

While, however, it is well to bear in mind our failure to give effect to our purpose twenty years ago, there are to-day advantages which we did not then possess. The economic distress and confusion into which the life of Europe had been thrown would have endangered any political system. The design of the League of Nations demanded much larger ideas and sympathies than those which guided the treaty makers at Versailles, and surrender to the passions of the hour placed fatal obstacles in the way of the success of the new system. The mistakes and failures of the past are ours to profit by in the attempt to build again on ampler lines.

Nor should we write off the League of Nations as a complete failure. One of the most encouraging features of the last two decades has indeed been the success of its work in certain technical fields such as health, communications and transport, the welfare of women and children. That work remains and continues, as does the work of its sister body, the International Labour Organisation, and their significance will increase.

Many believe that the real weakness of the present League of Nations lies in the retention of national sovereignty. They take the view that no system of collective security can be effective unless it is part of a plan for federal government. Essentially this point of view was foreshadowed by de Madariaga in 1937 in "Theory and Practice in International Relations", and more fully in his later "The World's Design". De Madariaga insists that the nations must discard the habit of thinking of foreign affairs because there are only world affairs, and that behind any machinery, such as the League or a reformed league, for world government, there must be a sufficient body of world citizens endowed with the necessary world patriotism to give world statesmen their inspiration and guidance.

It is on the foundation of a world community that de Madariaga bases his design, the building of world institutions such as a world administration to govern mandated territories, a world bank, a world trade commission and the utilization of existing international institutions, proceeding pari 
passu with the promotion of a sense of world citizenship. In the moral basis which he advocates, de Madariaga is arguing on similar lines to Curtius in his brilliant "Civitas Dei", and his contention that, by starting with certain practical problems, the professional interest in getting a problem properly solved may gradually come to eliminate others and substitute the disinterested, rational, exploratory type of mind for the acquisitive, the dogmatic or authoritative, will commend his approach to scientific workers.

Proposals of this type would conserve what is most worth while and possibly gain time for the development of a sufficiently advanced world opinion for acceptance of the idea of some form of federal government or union. This latter idea is outlined in detail in C. V. Streit's "Union Now". The general principle of a federal solution is reasonable in its fundamental premises, and many would be disposed to agree, at least in theory, with proposals to establish a federal government with supreme and single authority to use armed force against aggression by any nation or group outside the Federal Union, to control the use of raw materials in undeveloped territories now subordinate to its members, and to undertake the education of backward communities without racial discrimination.

For some such objectives as these much support could be found. The New Commonwealth, a body which has advocated the creation of an international police force, has been one among numerous factors disposing many to accept the limitations on national sovereignty involved in a federal or commonwealth solution. It is in the means to be taken to achieve a federal union, and the exact extent and nature of such a union that differences of opinion arise, and the practical difficulties are much greater than Mr. Streit is disposed to admit in his facile argument for union now.

Mr. Streit advocates a union of fifteen democracies of the North Atlantic, including a common citizenship, defence force, customs system, currency and postal and communication system. He urges that such a union would be so powerful in its combined resources as to assure peace to its members from the start through overwhelming preponderance and invulnerability. This number is chosen as the most practical nucleus for the organization of world government, and providing geographically, culturally, commercially, financially, politically, and historically, a cohesive nucleus. A start with the democracies is essential, because Mr. Streit proposes to base it on individual citizenship and not on the State itself as unit.

From this start Mr. Streit contemplates the growth of the Union into universal government by peaceful accession to its membership and by co-operation from the start with non-members. Despite, however, the force of Mr. Streit's contention regarding the rich heritage of the democracies in freedom and justice, we may well feel that he is unduly optimistic in arguing from American or Swiss experience as to the rate of progress in achieving such a federal union, and this view is not dispelled by his brusque treatment of the way in which the problems of a common defence force, currency, customs and postal systems are to be solved. Apart altogether from such details, there are other opinions as to the extent of federalism which should be our immediate objective, and the wisdom of scrapping entirely the experience and organization already obtained in international co-operation.

Mr. Streit's plan for union is based essentially on community of ideas and interests. An alternative to this is the Continental basis, essentially as advocated by Briand in his proposal for a European Union, though here also there is some community of ideas. Briand's plan, which lapsed largely through the refusal of Great Britain to link her fate with that of the Continent, has been revived in essence in the European Federation recommended by Count Coudenhove-Kalergi, who visualizes the world as moving towards a large group system. The Pan-American Union being organized by the United States and the Soviet Union are already examples, and a great Mongol block in the Far East is possible in the future. The peoples who care for justice, international law and the rights of men must work for the organization of Europe on good principles and under democratic influences, or that organization will be done by other hands.

A European federation might be easier to secure than the union advocated by Mr. Streit, and involve less risk in attaining it. The attitude of Great Britain will be as decisive a factor in achieving the United States of Europe as the attitude of the United States of America would be in the establishment of the Union of Mr. Streit's plan. What is most important, however, at the moment is not the choice between one plan and another, but the careful and impartial examination of the problems which have to be faced by any system of union, whatever the powers it bestows on the Federal Government. 
A main argument for Mr. Streit's plan is that the peoples embraced in his Union are all with long experience of Parliamentary government, and that their economic strength and command of essential materials would be able to assure peace. Count Coudenhove-Kalergi contends that this in itself would be a provocation to the non-democratic powers and would facilitate Germany's dream of creating a federation in Central and Eastern Europe in which she would play the part Prussia played in Bismarck's German federation. His plan would offer Germany and Italy a place in the federated Europe, and while their claims to domination would be resisted, the whole of Europe and a great part of Africa would be their living space.

Unquestionably a Europe organized on a basis of close co-operation between the several States would provide peaceful and constructive opportunities for the varied elements in Germany. Co-operation between such a federation and the Pan-American Union could scarcely fail to secure the peace of the world.

A major difficulty will, of course, be the safeguards to be provided against a repetition of aggression. It is for this reason that we must think of the settlement after the present war not simply in terms of ideals or of military or political force, but as an essentially practical problemthat of utilizing to the maximum the enduring moral and constructive forces which already exist and applying them to the changing conditions as well as supporting them with adequate combinations of force. This factor alone should render us chary of discarding too readily the League of Nations, and should induce us to examine rather more carefully than Mr. Streit has done the causes of its failure or impotency.

Mr. Streit's examination of the League is somewhat warped by preconceived ideas. The League and a federal system are not, as he assumes, necessarily opposed ideas. The League Covenant, for example, lays heavy limitations on national sovereignty, and under it the way is open for gradual and successive further surrenders of national sovereignty until an effective federal scheme is built up. There is at least reason for legitimate doubt whether, if the League has failed because its member States were unwilling to observe its more moderate limitations in their national sovereignty, there is any real prospect at the present time of their entering a federal system which involves an immediate and much more drastic surrender of the essentials of national sovereignty.

Granted that the federal idea probably offers the best ultimate prospect of achieving a lasting peace, the practical question is rather the steps by which we are to advance to that position, more especially when we take into account that the evolution of the British Commonwealth, for example, so far as the Dominions are concerned, is away from any kind of union. In such circumstances, it is imperative to build on any solid foundation that lies to hand.

Reference has already been made to experience and directions in which the work of the League of Nations and of the International Labour Organisation offers hope of further advance or success, and the studies or work on population questions, including migration, and on nutrition are of special promise in this respect. Beyond this we have in being to-day, in the Supreme Council and the Allied High Command, a standing organ of government with a powerful influence over two distinct Sovereign States, and a combination of armed forces under unified control. If these arrangements were kept functioning after the war, a nucleus would be provided on which an international body could be built.

If a way forward to increasingly close combination of European nations is at least possible, the forms of organization which the war is compelling us to adopt for negative purposes could equally be turned to the positive purpose of developing world resources by finding a beneficent outlet for the constructive energies of all peoples. Much progress has been made in establishing successful international commodity schemes, which form instruments of orderly development and are also powerful economic weapons. Steel, tin, zinc, aluminium, rubber, sugar, meat and other vital products are already under some form of international control. The technique of operating such controls is rapidly improving, and consumer interests are being increasingly brought to bear on their operation. This process would be assisted by the creation of an international supervisory body such as a Cartel Commission of the League of Nations, with strong personnel and powers to ensure publicity.

It is difficult to over-estimate the possibilities of such schemes. They have given the world an instrument for the scientific adjustment of expanding production to expanding consumption, thus reducing the chances of further acute world 
depressions, with their shocks to the stabilizing factors in international relations. The establishment of wind-breaks against economic blizzards of the severity of those of the period of 1929-32 is essential for peaceful and orderly political development.

Moreover, world economic organization appears to be approaching the point when international finance and trade can be greatly assisted by the concerted use of new methods. Internationally organized marketing, supported by international public works, might now be able to give for the first time a peaceful and lasting outlet for the world's energy comparable in scale with that which war supplied in the past. Already, impartial and scientific studies of such problems, often under the ægis of the League of Nations, have provided a basis for cash and price insurance schemes for the world's farmers, measures of conservation for soil, water, fauna and flora, education and health services and modern systems of taxation in backward countries, on a scale impossible even a few years ago. Here may lie a channel the further scientific exploration of which might provide a solution of the problems of colonies and raw materials.

The fact that in many fields the basis for a scientific attack on outstanding problems has already been provided is at least encouraging, and the possibilities of advance are greater than a quarter of a century ago, even if many difficulties remain. That the problems of reconstruction are already being discussed is a further hopeful sign, and evidence that the mistake of postponing until after victory in war the thought and study concerning the needs and structure of a new Europe will not be repeated. Preparation for the tasks of peace cannot be left until they suddenly and urgently arise, to be dealt with in an atmosphere of bitterness, weariness and economic chaos.

There is much to be said for the immediate appointment of a body of able and far-sighted men, chosen irrespective of party attachment, to begin at once the study of this most vital problem. In that study the co-operation of neutral countries should already be possible, and the way should be open for German co-operation immediately the present tyrannical leadership of that country has been replaced.

The contribution of scientific workers will be essential in the investigation of many of the problems of reconstruction which must be solved if we are to build a new Europe. The scientific spirit must be an effective influence if an impartial solution is to be obtained undisturbed by prejudice or vested interests ; and scientific workers no less than other members of the community have their part to play in seeing that the problems of peace are approached now in a magnanimous and serious spirit, with the courage, vision and resolution which are essential if a new order in Europe is to pass from a dream into reality.

\section{ISLAM'S CONTRIBUTIONS TO SCIENCE}

La science arabe et son rôle dans l'évolution scientifique mondiale

Par Aldo Mieli. Avec quelques additions de HenriPaul-Joseph Renaud, Max Meyerhof, Julius Ruska. Pp. xix +388 . (Leiden : E. J. Brill, Ltd., 1939.) 12.50 guilders.

$\mathrm{IT}^{\mathrm{T}}$ is only within the last half-century that systematic investigations have been made into the part played by Islam in the development of science. Earlier estimates of its importance were mainly conjectural and thus variable, religious prejudice tending to depreciation and the principle omne ignotum pro magnifico to exaggeration. One of the first serious attempts to set the inquiry upon a proper basis, by direct reference to original sources, was made by M. P. E. Berthelot, who in
1893 published the Arabic text of certain Muslim alchemical treatises in his "Chimie au Moyen Âge". Other very valuable pioneer work was carried out by E. Wiedemann (on Arabic chemistry and physics), M. Steinschneider (mainly bibliographical), H. Suter (on Muslim mathematicians), E. G. Browne, L. Leclerc and L. Choulant (medicine), and M. J. de Goeje (geography). More recently, Muslim chemistry and mineralogy have been closely studied by J. Ruska, H. E. Stapleton and P. Kraus ; medicine (particularly ophthalmology) by M. Meyerhof; mathematics by Salih Zaki of Istanbul; and Muslim philosophic thought in general by Baron Carra de Vaux and De Lacy O'Leary. This list, though representative, includes only a small fraction of the large band of scholars to whom the publication of very numerous Arabic 